\title{
Corruption and the shadow economy: an empirical analysis
}

\author{
Axel Dreher • Friedrich Schneider
}

Received: 18 October 2008 / Accepted: 16 September 2009 / Published online: 29 September 2009

(C) The Author(s) 2009. This article is published with open access at Springerlink.com

\begin{abstract}
This paper analyzes the influence of the shadow economy on corruption and vice versa. We hypothesize that corruption and the shadow economy are substitutes in high income countries while they are complements in low income countries. The hypotheses are tested for a cross-section of 98 countries. Our results show that there is no robust relationship between corruption and the size of the shadow economy when perceptions-based indices of corruption are used. Employing an index of corruption based on a structural model, however, corruption and the shadow economy are complements in countries with low income, but not in high income countries.
\end{abstract}

Keywords Corruption · Shadow economy $\cdot$ Regulation $\cdot$ Tax burden

JEL Classification $\mathrm{D} 73 \cdot \mathrm{H} 26 \cdot 017 \cdot 05$

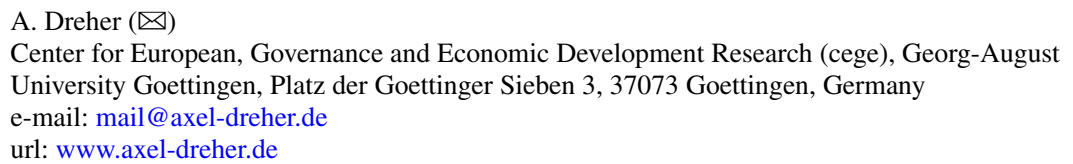

A. Dreher

KOF Swiss Economic Institute, Zurich, Switzerland

A. Dreher

IZA, Bonn, Germany

A. Dreher

CESifo, Munich, Germany

F. Schneider

Department of Economics, University of Linz, Altenbergerstraße 69, 4040 Linz-Auhof, Austria e-mail: friedrich.schneider@jku.at

url: www.econ.jku.at/schneider 


\section{Introduction}

In this paper we explore the relationship between the size of the shadow economy and corruption. ${ }^{1}$ We thereby combine two important topics. The first deals with the impact of corruption on the shadow economy; the second with the influence of the shadow economy on corruption. In both parts of the literature there are important gaps. Regarding the impact of corruption on the shadow economy, first, previous studies employ rather small samples. For example, Johnson et al. (1997) find that corruption affects the shadow economy positively (and the official economy negatively) — in a cross section of, however, only 15 countries. Similar results are presented in Johnson et al. (1998), with 39 countries in the relevant equation. Employing instrumental variables techniques and even reliable control variables was thus infeasible.

Second, the few studies investigating the impact of corruption on the shadow economy focus on rather heterogeneous country samples. There is no separation of high income and low income countries, the exception being Friedman et al. (2000), distinguishing Latin America, OECD and transition countries. However, Friedman et al. (2000) have only 15, 20 and, respectively, seven observations in their sample, so their results are far from reliable. Indeed, there is good reason to expect the relationship between corruption and the shadow economy to differ in high and low income countries. In high income countries, bribing government officials when detected engaging in the shadow market is rarely an option. Corruption might thus be independent of the size of the shadow economy. As Choi and Thum (2005) and Dreher et al. (2008) show, however, the shadow economy can mitigate government-induced distortions, so that corruption and the shadow economy could also be substitutes. Clearly, in high income countries entrepreneurs do not have to pay the bribes demanded by officials as they could always bring the corrupt officials to court. Consequently, they can choose by themselves whether to pay a bribe or operate underground. In low income countries, to the contrary, entrepreneurs engaging in the shadow economy can reasonably expect to escape prison when their illegal activity is detected. Officials collude with entrepreneurs and taxpayers in exchange for a bribe (e.g., Hindriks et al. 1999). By colluding with firms, corrupt bureaucrats can allow them to exploit profitable opportunities in the unofficial sector (Hibbs and Piculescu 2005). To what extent corruption and the shadow economy are complements or substitutes is thus likely to vary between high and low income countries.

Third, the existing evidence is contradictory and insufficient. Friedman et al. (2000) claim "corruption is associated with more unofficial economy." However, in the relevant instrumental variables regression, when controlling for the income level, this holds for only three out of eight indices employed (ibid.: 480). Further investigation-with a larger sample of countries-is needed.

Turning to the impact of the shadow economy on corruption, empirical evidence is virtually non-existent and the literature is not developed beyond the postulation of formal models. The exception is the recent analysis in Dreher et al. (2008), showing that corruption decreases with the size of the shadow economy.

Finally, the use of perceptions-based indices of corruption has recently been challenged. As one problem with these indices, it is not obvious what they actually measure. Arguably,

\footnotetext{
${ }^{1}$ We define corruption as the abuse of public power for private gains. Arguably, corruption, in the common usage of the word, can mean different things in different contexts. For a discussion of some of the alternative denotations of the problem of corruption and its damaging consequences see the insightful survey by Bardhan (1997). See also Klitgaard (1988), Rose-Ackerman (1999), and Otáhal (2007).
} 
opinions of citizens in countries with different institutional environments might vary according to their own idiosyncratic definitions. According to Mocan (2004), perceived corruption is completely unrelated to actual corruption once other relevant factors are controlled for. Similarly, Weber Abramo (2005) shows that perceived corruption is not related to the prevalence of bribery. ${ }^{2}$ To analyze empirically the relationship between corruption and the shadow economy using a measure of corruption that is not based on perceptions is thus clearly warranted.

This paper makes an attempt to fill these gaps. We employ a substantial number of estimates of the size of the shadow economy based on the same method and all coming from the same source. We employ a cross-section of 98 countries over the 1999-2002 period to empirically analyze the relationship between corruption and the size of the shadow economy. ${ }^{3}$ We use an index of corruption based on a structural model in addition to the usual perceptions-based measures. The index has been developed in Dreher et al. (2007) and is based on the likely causes and consequences of corruption. The country sample is split into high and low income countries in order to gain additional insights about the relationship between corruption and the shadow economy.

To anticipate the results, there is no robust relationship between corruption and the shadow economy when perceptions-based indices of corruption are used. Employing an index of corruption based on a structural model, however, the results show that corruption and the shadow economy are complements in countries with low income, while there is no robust relationship in high income countries.

The paper is organized as follows. In Sect. 2 we derive our hypotheses, while Sect. 3 discusses the data and method of estimation. In the fourth section we present the empirical results. Finally, Sect. 5 concludes.

\section{Hypotheses}

Theoretically, corruption and the shadow economy can either be complements or substitutes. Choi and Thum (2005) present a model where the option of entrepreneurs to go underground constrains a corrupt official's ability to ask for bribes. Dreher et al. (2008) extend the model to the explicit specification of institutional quality. The model shows that corruption and the shadow economy are substitutes in the sense that the existence of the shadow economy reduces the propensity of officials to demand sub rosa payments.

Johnson et al. (1997), to the contrary, model corruption and the shadow economy as complements. In their full-employment model, labor can either be employed in the official sector or in the underground economy. Consequently, an increase in the shadow economy always decreases the size of the official market. In their model, corruption increases the shadow economy, as corruption can be viewed as one particular form of taxation and regulation (driving entrepreneurs underground). According to Hibbs and Piculescu (2005), corrupt bureaucrats can overlook unofficial production in exchange for a bribe, so that corruption increases the size of the underground sector. Hindriks et al. (1999) also show that the shadow economy is a complement to corruption. This is because, in this case, the taxpayer colludes with the inspector so the inspector underreports the tax liability of the taxpayer in exchange for a bribe. ${ }^{4}$

\footnotetext{
${ }^{2}$ See Søreide (2005) for further criticism of perceptions-based indices of corruption.

${ }^{3}$ Appendix D contains a list of countries included in the empirical analysis.

${ }^{4}$ See Dreher and Siemers (2009) for a formalization of this argument. See also El-Shagi (2005).
} 
Theoretically, the relationship between corruption and the shadow economy is thus unsettled. There is, however, reason to believe that the relationship might differ among high and low income countries. In high income countries, the official sector provides public goods like the rule of law, enforcement of contracts, and police protection. Usually, only craftsmen or very small firms have (or take) the option of going underground. In this case, the shadow economy is hidden from tax inspectors and other officials. In other words, there are no bribes necessary or possible to buy one's way out of the official sector. In high income countriestypically showing comparably small levels of corruption-individuals confronted with a corrupt official have the option of bringing the official to court. Moreover, in high income countries corruption quite often takes place to bribe officials to get (huge) contracts from the public sector (e.g., in the construction sector), which are then handled in the official economy and not in the shadow economy. Hence, corruption in high income countries can be a means of achieving certain benefits which make work in the official economy easier, e.g., winning a contract from a public authority, getting a licence (e.g., for operating taxes, providing other services, or getting permission to convert land into "construction ready" land). ${ }^{5}$ In high income countries people thus bribe in order to be able to engage in more official economic activities. As Schneider and Enste (2000) point out, at least two-thirds of the income earned in the shadow economy is immediately spent in the official sector. The shadow economy and the official sector might thus be complements. The corresponding increase in government revenue and strengthened institutional quality is likely to decrease corruption. The prediction of a negative (substitution) relation between corruption and the shadow economy is in line with the models of Choi and Thum (2005) and Dreher et al. (2008).

In low income countries, to the contrary, we expect different mechanisms to prevail. Instead of working partly in the official sector and offering additional services underground as in high income countries, enterprises completely engage in underground activity. ${ }^{6}$ Examples of enterprises operating completely underground are restaurants, bars, or haircutters - and even bigger production companies. As one reason for this, the public goods provided by the official sector are in many developing countries less efficient as compared to high income countries. Big companies, however, are comparably easy to detect and-in order to escape taxation and punishment - they have to bribe officials, thereby increasing corruption. Corruption often takes place in order to pay for activities in the shadow economy, so that the shadow economy entrepreneur can be comparably sure not to be detected by public authorities. Here, the shadow economy and corruption are likely to reinforce each other, as corruption is needed to expand shadow economy activities and - at the same time-underground activities require bribes and corruption. To get some additional income from the shadow economy entrepreneur, it is natural for public officials to ask for bribes and thus benefit from the shadow market. In low income countries, we therefore expect a positive (complementary) relation between corruption and the shadow economy. This corresponds to the predictions of the models of Hindriks et al. (1999), Johnson et al. (1997) and Hibbs and Piculescu (2005).

In summary we expect:

Hypothesis 1 In low income countries, shadow economy activities and corruption are complements.

\footnotetext{
${ }^{5}$ The argument is related to theories according to which corruption oils the wheels of the system (see, e.g., Méon and Sekkat 2005; Méon and Weill 2006).

${ }^{6}$ See, e.g., Gerxhani (2003), Johnson et al. (1997), and Schneider (2005b).
} 
Hypothesis 2 In high income countries, shadow economy activities and corruption are substitutes.

The next section outlines our method of estimation and presents the data.

\section{Data and estimation technique}

We estimate OLS regressions for a cross-section of countries taking the following form ${ }^{7}$ :

$$
Y_{i}=\alpha+\beta_{1} X_{i}+\beta_{2}^{\prime} Z_{i}+\varepsilon_{i},
$$

where $Y$ and $X$ represent either corruption or, respectively, the shadow economy and $Z$ is a vector of control variables. In order to increase the number of observations, all data are averages over the 2000-2002 period.

Data for the shadow economy are taken from Schneider (2005a, 2005b). Schneider calculates the size and development of the shadow economy of 145 countries. In a first step Schneider (2005b) estimates the size of the shadow economy with the help of the MIMIC method. ${ }^{8}$ While the MIMIC approach produces estimated relative sizes of the shadow economy, another step is necessary to get to absolute values. In order to calibrate absolute figures of the size of the shadow economies from the relative MIMIC estimation results, Schneider uses previous estimates for a number of countries (e.g., Australia, Austria, Germany, Hungary, Italy, India, Peru, Russia and the United States). ${ }^{9}$

The resulting average size of the shadow economy as a percentage of official GDP in the 37 African states is $41 \%$ in 1999/2000, and 43\% in 2002/2003. In Central and South America the size of the shadow economy amounts to $41 \%$ in 1999/2000 (and 43\% in 2002/2003). In Asia the average value is much lower (29\% for the year 1999/2000; $30 \%$ in 2002/2003). Regarding the transition countries among the sample, the respective values were $38 \%$ and $40 \%$; for the OECD $17 \%$ and, respectively, $16 \%$. Looking at the unweighted average of the 145 countries in the sample, the average size of the shadow economy was 34\% in 1999/2000 and $35 \%$ in $2002 / 2003$.

To measure corruption, we employ a well-known and widely used index provided by the International Country Risk Guide. This indicator is based on the analysis of a world-wide

\footnotetext{
${ }^{7}$ In the working paper version of this paper, we also estimated panel regressions. However, missing observations substantially reduced the number of countries included in the analysis, challenging the reliability of the results. We therefore decided to omit the panel regressions.

${ }^{8}$ The dynamic multiple-indicators multiple-causes (MIMIC) method is based on the statistical theory of unobserved variables, which considers multiple causes and multiple indicators of the phenomenon to be measured. For the estimation, a factor-analytic approach is used to measure the hidden economy as an unobserved variable over time. The unknown coefficients are estimated in a set of structural equations within which the "unobserved" variable cannot be measured directly. The MIMIC model consists in general of two parts, with the measurement model linking the unobserved variables to observed indicators. The structural equations model specifies causal relationships among the unobserved variables. In this case, there is one unobserved variable - the size of the shadow economy — which is assumed to be influenced by a set of causes and indicators for the shadow economy's size. The exact causal and indicator variables used are listed in the definitions of Appendix B.

${ }^{9}$ These external estimates are derived employing the currency demand method. For the sources of these external estimates see Schneider (2005b, p. 21).
} 
network of experts. ${ }^{10}$ On the original scale, the index has a range from 0 -representing highest corruption - to 6 (no corruption). We rescaled the index, so that higher values represent greater corruption. We have 98 countries in our sample for which both data for the shadow economy, corruption, and the relevant control variables are available.

We take account of the recent critique of perceptions-based indices of corruption employing an alternative indicator below. The index has been developed in Dreher et al. (2007) and is based on a structural model. The statistical method applied infers the magnitude of corruption from both the likely causes and likely effects of corruption. ${ }^{11}$ The index is available for about 100 countries for the year 2000 and ranges from 1 to 10, where higher values represent higher corruption. The Multiple Causes, Multiple Indicators (MIMIC) method used to derive the index is similar to the one employed in Schneider (2005a, 2005b) to estimate the size of the shadow economy. While having the advantage of being largely independent of perceptions, the index arguably also implies drawbacks, in particular the necessarily ad hoc decision of which causes and indicators to employ. ${ }^{12}$

Regarding our control variables, we follow Johnson et al. $(1997,1998)$ and Friedman et al. (2000). Our covariates thus belong to three groups: tax rates and government revenues, measures of regulation, and proxies for institutional quality. ${ }^{13}$ Our measures of institutional quality and regulatory burden are from Gwartney and Lawson (2004), the Heritage Foundation (2005), Marshall and Jaggers (2008), and Kaufmann et al. (2003). Except for the index of corruption, we have kept the original signs of the variables, so that different organizations' ratings differ as to whether a high numerical value corresponds to "better" values.

Johnson et al. $(1997,1998)$ argue that the shadow economy can be expected to be larger when there is more regulation and thus more discretion for officials. Politicians might use the right to regulate to pursue their own interest, such as supporting allies. Politicians can also use the right to regulate to enrich themselves by offering relief from regulation in exchange for bribes (Shleifer and Vishny 1993; Dreher and Siemers 2009). We thus expect regulations to imply a larger shadow economy, and greater corruption. Specifically, we employ seven measures produced by the Heritage Foundation and the Fraser Institute. The Fraser Institute's measures range from 0 to 10 , where higher values indicate fewer regulations. The indices refer to regulations in the credit market, minimum wage regulation, price regulation, administrative procedures, and the time spent with government bureaucracy. We take two indices from Heritage. The first measures wage and price regulation, the second is an overall measure of the degree of regulations in the economy. The scale ranges from 1 to 5, with higher values indicating regulations that are worse for business.

As firms in the unofficial sector largely escape taxation, a higher share of the informal sector should be correlated with lower tax revenue (relative to GDP). However, a heavy fiscal burden is likely to drive enterprises underground, a result obtained by Loayza (1996) for Latin America and by Johnson et al. (1997) for transition economies. A huge fiscal burden

\footnotetext{
${ }^{10}$ Note that the focus of this index is on capturing political risk involved in corruption. Since it is the only perception-based data on corruption providing consistent time series, the index has nevertheless been widely used in empirical studies.

${ }^{11}$ More specifically the causal indicators include the rule of law and school enrollment, while the consequences employed refer to cement consumption, private credit availability, GDP per capita, and capital account restrictions.

${ }^{12}$ For a more detailed critique, see Helberger and Knepel (1988).

${ }^{13} \mathrm{We}$ focus on formal institutions here. For an excellent analysis of the relationship between informal institutional quality and the underground economy see D'Hernoncourt and Méon (2008). In particular, D’Hernoncourt and Méon find that generalized trust reduces the size of the shadow economy.
} 
should thus increase the size of the shadow economy. Regarding corruption, bribes are paid to avoid paying taxes, so that corruption should increase with the fiscal burden. We use the Heritage Foundation's measure of fiscal burden, referring to average and marginal corporate and personal income taxation. Its index of tariff and non-tariff barriers to trade captures international trade taxation and regulation. A higher score (on a scale of 1-5) implies more burdensome taxation, i.e., higher average and marginal tax rates and, respectively, higher taxes on trade. The Fraser Institute's measures of taxes (Gwartney and Lawson 2004) show higher scores for countries with lower tax rates, on a scale of 1-10. We employ their indices for the top marginal income tax rate and taxes on international trade. In addition, we employ tax revenue and overall revenue (both relative to GDP) from the World Bank's (2003) World Development Indicators.

Better institutional quality, finally, increases the benefits entrepreneurs can derive from operating in the official sector, most likely leading to a reduction of the unofficial sector. ${ }^{14}$ Almost by definition, better institutions also imply lower levels of corruption. ${ }^{15}$ Better institutional quality should thus reduce corruption and the size of the shadow economy alike.

Regarding institutional quality, we employ three indices constructed by the Fraser Institute, and two from the World Bank (Kaufmann et al. 2003). On the scale of the Fraser indices (0-10), higher values imply a "better" legal system. We employ their indices for judicial independence, impartial courts, and the integrity of the legal system. The World Bank's government effectiveness and rule of law indicators range from -2.28 to 2.59 and, respectively, -2.04 to 2.36 , with higher scores showing "better" environments. We also use the Polity IV index of democracy, ranging from -10 to 10 , with higher values indicating more democracy.

Again following the previous literature, each regression also includes the log of per capita GDP, taken from the World Bank's (2003) World Development Indicators. Appendix B lists all variables with their exact sources and definitions; Appendix $\mathrm{C}$ reports descriptive statistics.

In order to select the specific control variables among the substantial list provided above, we included all variables at the same time and followed a general-to-specific-approach, eliminating those variables with the smallest $t$-value until we end up with a model containing only those variables (in addition to per capita GDP, the index of corruption and, respectively, the shadow economy) that are significant at the $10 \%$ level at least.

The sample is then split in two income (per capita) groups to test our hypotheses. ${ }^{16} \mathrm{We}$ follow the World Bank's definition of lower middle income countries and include countries in the first group when their 2004 GNI per capita does not exceed US $\$ 3,255$, and in the second otherwise. Depending on which covariates are included in the regressions, there are between 43 and 71 countries in the low income group. The number of countries with high income is between 23 and 27. Due to the substantially reduced number of observations we have to interpret the results of some regressions cautiously.

Arguably, the determinants of corruption and, respectively, the shadow economy, might differ among low and high income countries. Consequently, running separate general-tospecific analyses and including the most important variables for the particular sub-samples

\footnotetext{
${ }^{14}$ Such benefits can be direct and, in addition, indirect, by increasing, e.g., economic growth or foreign direct investment (Méon and Sekkat 2004).

${ }^{15}$ Arguably, the absence of corruption is one feature of institutional quality. More specifically, we therefore control for aspects of institutional quality other than corruption in the empirical analysis below.

${ }^{16}$ We choose to split the sample instead of using interaction terms as specification tests reject most of the regressions including all countries but accept most sub-sample regressions.
} 
comes to mind. However, the regressions for the sub-samples cannot be estimated as the number of variables exceeds the number of observations in the full models. We therefore added all excluded variables one at the time to the model derived from the general-to-specific analysis for the full sample and kept those that are significant at the $10 \%$ level at least. As will be seen below, the results for the sub-samples are in most cases identical to the full sample.

As a potential problem with our data, some of the variables entering the regressions below have been used to construct the measure of the shadow economy employed here, and are included in constructing the measure of corruption (based on a structural model) at the same time. While the indices are not simply linear combinations of the underlying causes and indicators, but are constructed by attributing the correlation of the causes and indicators to the latent variables "shadow economy" and, respectively, "corruption," it would not be surprising for these variables to show up as significant determinants of the latent variables. Excluding these control variables, however, would result in omitted variable bias. In any case, our main interest is not in these control variables, but in the effects of corruption and, respectively, the size of the shadow economy on each other. Still, we test for the robustness of our main results by using an alternative measure of the size of the shadow economy, based on the physical input method.

Clearly, taking corruption and the shadow economy as exogenous determinants of each other contradicts our a priori hypotheses. We therefore employ instrumental variables to deal with the potential endogeneity of corruption and the shadow economy. As an obvious problem, identifying valid instruments is a real challenge: finding something that affects corruption and that has no relationship with the informal economy other than through corruption is difficult; similarly, it is difficult to find something that affects the informal economy and has no relationship with corruption other than through the informal economy. We employ two sets of instruments for each variable. First, the determinants of corruption and the shadow economy identified in the general-to-specific-approach are employed. Second, we use the instruments for corruption suggested by Friedman et al. (2000): Ethnic and religious fractionalization, a country's latitude, and French, socialist, German, and Scandinavian legal origin. The variables have been shown to be correlated with institutional development across a wide range of countries (La Porta et al. 1999). Regarding the shadow economy, a range of variables determining the costs of doing business in a country have recently been developed by the World Bank (Djankov et al. 2002). According to the results of Friedman et al. (2000) entrepreneurs go underground mainly to reduce the burden of bureaucracy. The variables measuring the costs of and the time required to open a business as well as flexibility with respect to hiring and firing workers thus appear to be natural instruments for the shadow economy. We employ them as our second set. Clearly, it is not a priori obvious that all of these variables are valid instruments. ${ }^{17}$ We rely on the usual statistical tests to answer this question.

Our second equation takes the form:

$$
X_{i}=\gamma_{1}^{\prime} I_{i}+\varepsilon_{i}
$$

with I representing the vector of instrumental variables. $F$-tests on the joint significance of our instruments show that they are good predictors of the degree of corruption and, respectively, the shadow economy. As the $F$-tests in the tables below indicate, the Staiger-Stock critical value of 10 is easily passed in the full samples, but not in the samples split according

\footnotetext{
${ }^{17}$ For example, corrupt government officials might intentionally increase the amount of regulation and red tape in order to be able to extract bribes (see Dreher and Siemers 2009), and will thereby drive firms underground.
} 
to income. In most (but not all) cases, the overidentifying restrictions are also not rejected at conventional levels of significance.

The next section presents the results.

\section{Empirical results}

Column 1 of Table 1 presents the OLS results of the full model explaining the size of the shadow economy resulting from the general-to-specific analysis. In the overall sample, only three variables are significantly correlated with the unofficial sector, at the $1 \%$ level. As can be seen, the shadow market shrinks with stronger regulations in the credit market, contradicting our a priori expectation. Government effectiveness reduces the size of the informal sector. This is intuitive: the more effective the government, the greater the benefits of operating in the legal sector. Moreover, the risk of getting caught engaging in illegal activities is greater with more effective governments. Stronger minimum wage regulation also increases the size of the shadow economy. The results also show, surprisingly, that our measures of tax burden are not selected by the general-to-specific analysis. As Hibbs and Piculescu (2005) argue, high tax rates do not necessarily imply large shadow economies, as the incentives to evade taxes and produce in the shadow economy depend on tax rates relative to firm-specific benefits available to firms producing in the official sector.

Turning to the results for low and, respectively, high income countries-also reported in column 1 -only one additional variable is significant at the $10 \%$ level at least when adding one variable at the time as described above to the regression for the low income sample. No additional variable is selected in the sample including only countries with high income. The results for the sample of countries with low income are similar to the full sample, with the exception that per capita GDP is now significant at the $10 \%$ level, with the expected negative coefficient. In addition, the size of the shadow economy decreases at the $10 \%$ level of significance with stricter regulations of wages and prices, as measured by the Heritage Index. Given that we already control for minimum wage regulation by including the respective Fraser index, this result is likely to be due to price rather than wage regulation. Still, it is surprising.

In the high income sample, credit market regulations and minimum wage regulations are not significant at conventional levels, while GDP per capita is significant at the $10 \%$ level, again with the expected negative coefficient.

With few exceptions, the results are identical when employing the 2SLS approach in columns 2 and 3. However, employing the first set of instruments (column 2), minimum wage regulation enters positively in high income countries (at the $10 \%$ level of significance). Using the second set of instruments (column 3), credit market regulations are no longer significant at conventional levels in the overall sample, GDP per capita is not significant at conventional levels throughout, and wage and price regulations are marginally insignificant in the low income sample. The Sargan test does not reject the overidentifying restrictions at conventional levels of significance in all but the final regression (column 3, high income countries), where the restrictions are rejected at the $10 \%$ level of significance, but not at the 5\% level. Table A.1 in the Appendix shows the correlation between the two sets of instruments and the residuals of the full model. According to the table, the correlation between the instruments and the residuals is reasonably low. The table also shows the comparably high correlation between most of the instruments and the dependent variable (corruption). The Anderson canonical correlations LR statistic and the Cragg-Donald chi-sq statistic-both tests of whether the equation is identified, do not reject the specification at conventional levels of significance. 


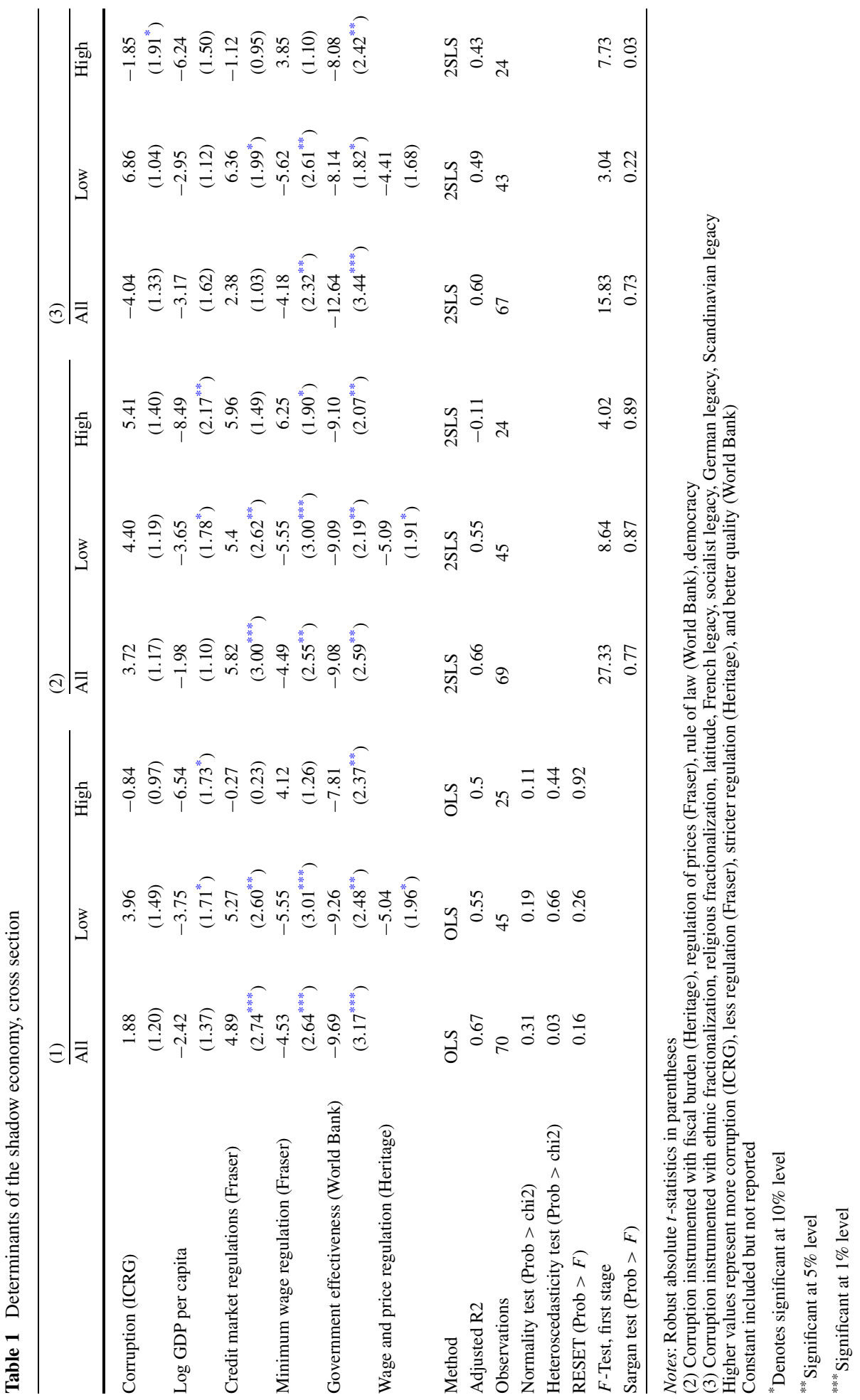


Turning to one of our variables of main interest, Table 1 shows that corruption does not significantly affect the size of the shadow economy. As the only exception, corruption seems to reduce the size of the shadow economy in high income countries according to column 3. However, as the instruments are rejected in this specification, this result is likely to be spurious. The insignificant result is in contrast to the results of Johnson et al. (1998) reporting corruption to be among the major determinants of the unofficial sector. However, their regressions neglect the impact of institutional and governmental quality. Once institutional quality and government effectiveness are taken into account corruption apparently has no significant impact on the size of the shadow economy. The results support Bjørnskov (2006), showing that a perceptions-based index of corruption cannot be separated statistically from other indices of governance. Similarly, Weber Abramo (2005) argues that perceptions-based indices reflect the quality of a country's institutions rather than its actual degree of corruption. Controlling for other dimensions of institutional quality, corruption consequently has no effect on the size of the shadow economy.

Table 2 reports the results for the full model explaining perceived corruption. ${ }^{18}$ Estimated with OLS (column 1), price regulation is positively correlated with corruption in the overall sample, while corruption is lower with better rule of law, greater democracy, ${ }^{19}$ and heavier fiscal burden, at least at the $10 \%$ level of significance. At conventional levels of significance, GDP per capita has no impact on corruption in the overall sample - and neither does the shadow economy. However, a larger shadow economy is negatively correlated with corruption in high income countries, with a coefficient significant at the $1 \%$ level. Corruption and the shadow economy thus seem to be substitutes in high income countries. Quantitatively, a ten percentage point increase of the shadow economy (relative to GDP) reduces the index of corruption by 0.7 points in high income countries, with a standardized regression (beta) coefficient of 0.47. However, columns 2 and 3 show that this result does no longer hold when instrumenting for the size of the shadow economy. This is true in the overall sample as well as in high and low income countries.

In summary, corruption and the size of the shadow economy do not seem to significantly affect each other in our cross-section of countries. Potentially, this result might be due to the use of a specific index, the ICRG index of perceived corruption. We therefore test for the robustness of our results employing two alternative indicators of perceived corruption. The first is the corruption perceptions index developed by Transparency International (TI), ranging from zero to ten. The second index is from the World Bank's 'governance matters' database (Kaufmann et al. 2003) with values between -1.85 and 2.58. The results show, however, that there is no significant relationship between corruption and the shadow economy when the TI index is used (not reported in tables). There is one exception: In high income countries, corruption decreases with a larger shadow economy, with a coefficient significant at the 5\% level according to the OLS regression. This result holds when the World Bank index of corruption is used instead. No other regression, however, shows a significant relation between the World Bank index and the size of the shadow economy. We therefore do not report these regressions in a table.

\footnotetext{
${ }^{18}$ As can be seen in Appendix Table A.1, the correlation between the instruments and the residuals is again reasonably low, while there is a comparably high correlation between most of the instruments and the size of the shadow economy.

${ }^{19}$ This is in line with Aidt and Gassebner (2007), arguing that the lack of monitoring capability in autocracies enables the bureaucracy to generate additional red tape (thus increasing corruption).
} 


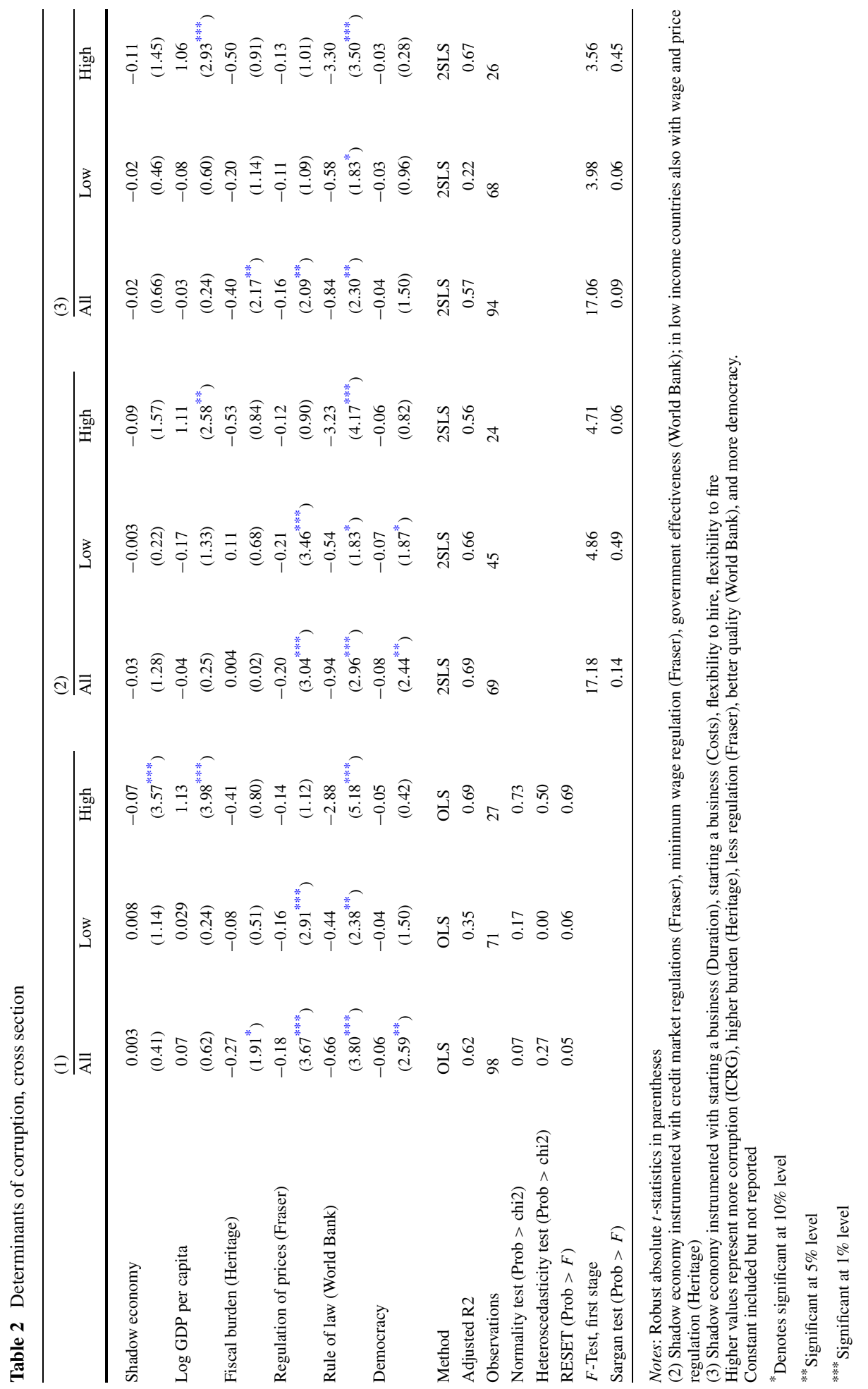


It has been argued that perceptions-based indices are not free of problems. One such problem refers to the low correlation between perceived corruption and actual corruption. According to Mocan (2004) the two are completely unrelated once other relevant factors are controlled for. Similarly, Weber Abramo (2005) shows that perceived corruption is not related to bribery. ${ }^{20}$ Our results might thus arise from using perceived corruption, rather than real corruption. We employ an alternative index of corruption based on a structural model, as introduced above.

When replicated with the index of corruption based on a structural model the regressions show that corruption does not significantly influence the size of the underground sector in any regression. We do therefore not present the results in a table. However, there is a significant impact of the shadow economy on corruption. The results are presented in Table 3.

As can be seen, corruption increases with the size of the underground sector in the overall sample, with coefficients significant at the $10 \%$ level according to the OLS regression (column 1) and at the 5\% level when using the two sets of instruments (columns 2 and 3 ). The disaggregated results show that the positive impact of the shadow economy on corruption is driven by low income countries, with a coefficient significant at least at the $10 \%$ level in all three regressions. The magnitude of the coefficient is economically relevant. In low income countries, a one percentage point increase in the shadow economy (in \% of GDP) increases the index of corruption by between 0.06 and 0.12 points. While the Sargan test does not reject all but one specification at conventional levels of significance, note, though, that while the instruments are jointly significant at the $10 \%$ level at least in the overall and low income samples, the $F$-statistics on the instruments in the first stage regressions show that the instruments are rather weak.

As a final check for robustness, we test whether the impact of the shadow economy on corruption is robust to the specific measure of the shadow economy employed. We therefore use data calculated with the Physical Input (Electricity Consumption) Method, taken from Schneider and Enste (2000). This approach takes electric-power consumption as physical indicator of overall (official plus unofficial) economic activity. Overall economic activity and electricity consumption have been observed empirically to move in lockstep, with an electricity to GDP elasticity usually close to one. This means that the growth of total electricity consumption is an indicator for growth of overall GDP. Subtracting the estimates of official GDP from this overall measure, unofficial GDP can be derived. Unfortunately, these data are available for 48 countries only. Given that our interest is on the differential impact of the shadow economy in low and, respectively, high income countries, we complement these data with the MIMIC data used so far when the physical input data are missing. In the full sample, about half of the observations are thus estimated with the physical input method, while the other half is estimated employing the MIMIC method.

Table 4 reports the results. As can be seen, the impact of the size of the shadow economy is not significant at conventional levels according to the OLS results of column 1. However, using the same sets of instrumental variables as before, the results mirror those reported in Table 3. We thus conclude that the results are robust as to how we measure the size of the shadow economy.

\footnotetext{
${ }^{20}$ Arguably, surveys are not particularly suitable for comparisons of a large sample of countries, as opinions of citizens in particular countries vary according to their own different definitions of corruption determined by their formal and informal institutional environments. Interestingly, perceived corruption is also unrelated to participation in the Extractive Industries Transparency Initiative (EITI), arguably a measure for intended reforms against corruption (Pitlik et al. 2009).
} 


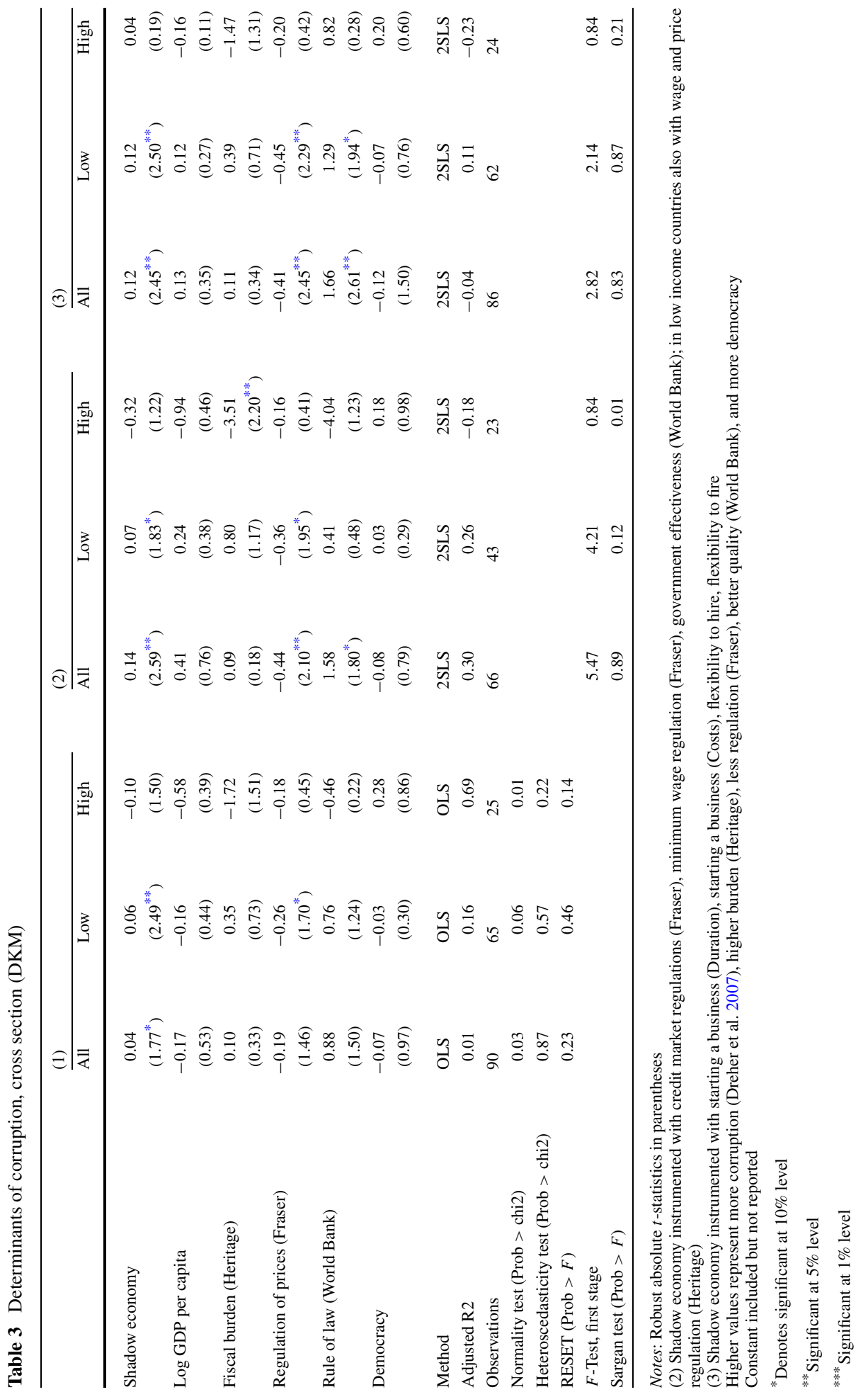




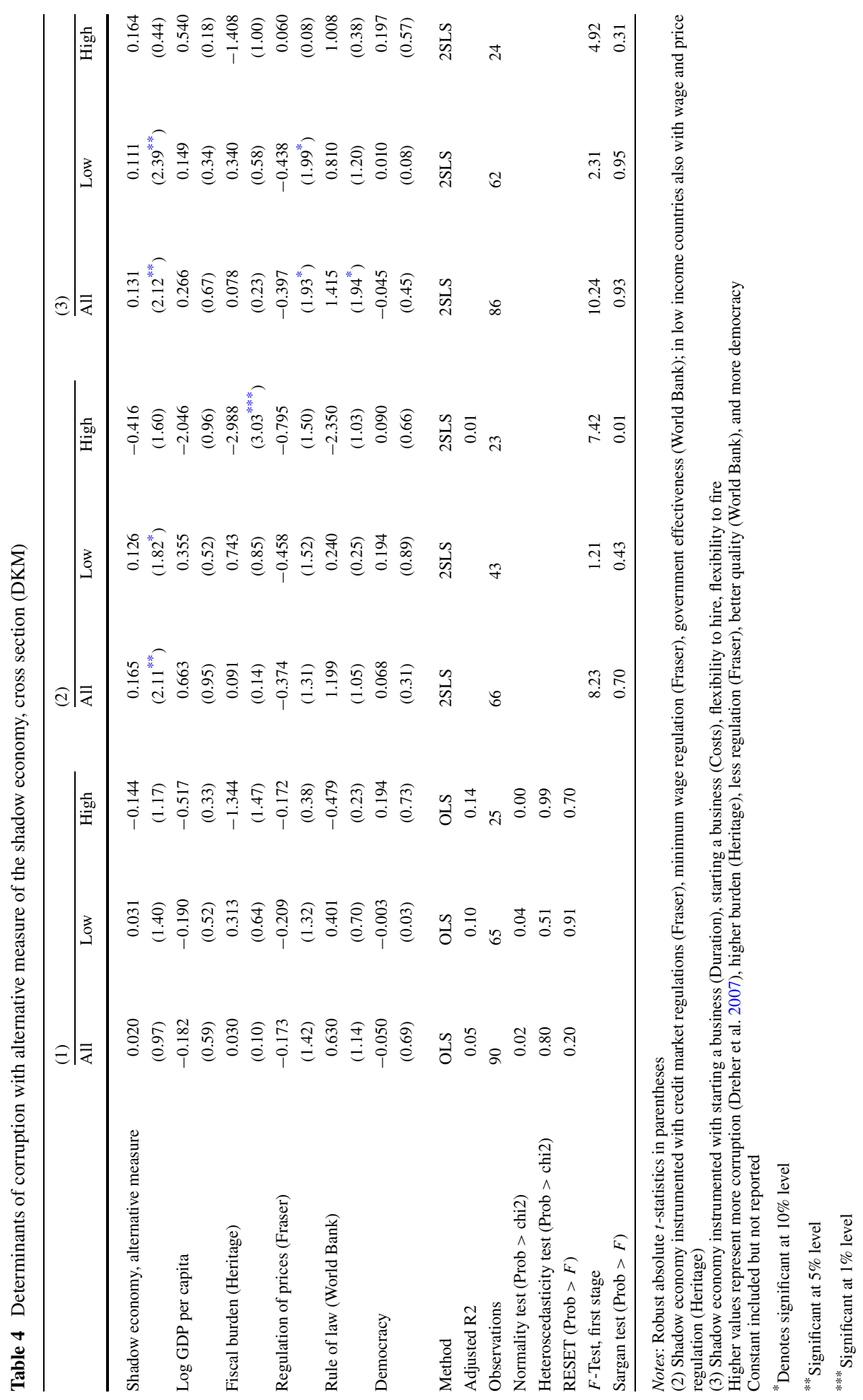


In summary, however, there is at best weak evidence for our a priori hypotheses. Using perceptions-based indices of corruption, our results show that there is no robust relationship between corruption and the size of the shadow economy. Employing an index of measured corruption the results show that the size of the shadow economy does not affect corruption at conventional levels of significance. However, employing the shadow economy as dependent variable, corruption and the shadow economy are complements in countries with low income, in line with Hypothesis 1. There is no robust significant relationship in high income countries.

\section{Conclusions}

In this paper we addressed the dual relationship between corruption and the size of the shadow economy. We hypothesized that the shadow economy and corruption are substitutes in high income countries. In low income countries, to the contrary, we expected the shadow economy and corruption to be complements. The empirical findings provide only weak support for our hypotheses. Our results show that there is no robust relationship between corruption and the shadow economy when perceptions-based indices of corruption are used. Employing an index of measured corruption, the results show that corruption and the size of the shadow economy are complements in countries with low income, while there is no robust relationship in high income countries.

What conclusions can we draw from these results? In general we must admit we have no clear and robust pattern that confirms our hypotheses among the range of indicators and specifications employed. In low income countries we find that measured corruption increases with a larger shadow economy, confirming the models of Johnson et al. (1997, 1998), Hindriks et al. (1999) and Hibbs and Piculescu (2005), and suggesting that corruption and the shadow economy are complements in these countries.

Clearly, one of the most important problems in empirical studies of corruption and the shadow economy is the unavailability of high quality data over time. Our analysis confirms the importance of the choice of indicator on the results. If we use measured corruption figures as calculated by Dreher et al. (2007) instead of indices of perceived corruption our results show a strongly significant impact of the shadow economy on corruption in low income countries, while there is no effect when we focus on perceived corruption. Our results thus lend support to recent evidence that perceived corruption cannot statistically be separated from other dimensions of institutional quality but might instead reflect peoples' overall perceptions of a country's institutional environment (e.g., Bjørnskov 2006). Ideally, we would thus like to test our hypotheses with consistent panel data of corruption based on a structural model. However, such data do not exist, ${ }^{21}$ and given the hidden nature of corruption and the size of the shadow economy expecting clear-cut results might arguably be too ambitious.

Acknowledgements We thank Jens Andvig, Johann Graf Lambsdorff, Pierre-Guillaume Méon, Lars-H.R. Siemers, Dana Sisak, Tina Søreide, Johannes Verbeek and participants at seminars at the European Public Choice Society (Turkku 2006), American Public Choice Society (New Orleans 2006), German Economic Association (Bayreuth 2006), the European Economic Association (Vienna 2006), and the Münster 2009 conference on the Shadow Economy, Tax Evasion and Social Norms for helpful comments on an earlier draft.

${ }^{21}$ While the ICRG index of corruption is available on a yearly basis, data on the shadow economy are not. The MIMIC data provided by Schneider (2005a, 2005b) exist for three periods of time, while most indicators of institutional quality are available for some years, but only occasionally overlap with these periods. 
Open Access This article is distributed under the terms of the Creative Commons Attribution Noncommercial License which permits any noncommercial use, distribution, and reproduction in any medium, provided the original author(s) and source are credited.

\section{Appendix A}

Table A.1 Instruments for corruption and the shadow economy

\begin{tabular}{|c|c|c|}
\hline & \multicolumn{2}{|l|}{ Correlations corruption } \\
\hline & Residuals of full model & Corruption (ICRG) \\
\hline Corruption (ICRG) & \multicolumn{2}{|l|}{-0.00} \\
\hline Log GDP per capita & 0.02 & -0.64 \\
\hline Fiscal burden (Heritage) & -0.03 & 0.03 \\
\hline Regulation of prices (Fraser) & 0.01 & -0.60 \\
\hline Rule of law (World Bank) & -0.00 & -0.74 \\
\hline Democracy & -0.10 & -0.54 \\
\hline Corruption (ICRG) & \multicolumn{2}{|l|}{-0.00} \\
\hline Ethnic fractionalization & 0.13 & 0.34 \\
\hline Religious fractionalization & -0.02 & -0.03 \\
\hline Latitude & -0.12 & -0.50 \\
\hline French legal origin & -0.01 & 0.13 \\
\hline Socialist legal origin & -0.18 & 0.14 \\
\hline German legal origin & -0.02 & -0.18 \\
\hline \multirow[t]{3}{*}{ Scandinavian legal origin } & 0.18 & -0.47 \\
\hline & \multicolumn{2}{|c|}{ Correlations shadow economy } \\
\hline & Residuals of full model & Shadow economy \\
\hline Shadow economy & \multicolumn{2}{|l|}{0.05} \\
\hline Log GDP per capita & -0.15 & -0.71 \\
\hline Credit market regulations (Fraser) & -0.37 & -0.37 \\
\hline Minimum wage regulation (Fraser) & -0.04 & -0.49 \\
\hline Government effectiveness (World Bank) & -0.13 & -0.76 \\
\hline Shadow economy & \multicolumn{2}{|l|}{0.01} \\
\hline Starting a business (Duration) & -0.21 & 0.32 \\
\hline Starting a business (Costs) & -0.16 & 0.49 \\
\hline Flexibility to hire & -0.19 & 0.20 \\
\hline Flexibility to fire & -0.12 & 0.43 \\
\hline
\end{tabular}

Notes: The upper panel reports the correlation between the residuals of the full model explaining the shadow economy (Table 1, columns 2 and 3) and the instruments as well as the correlation between the instruments and corruption. The lower panel reports the same for the full model explaining corruption (Table 2, columns 2 and 3). All correlations are restricted to the respective estimation sample 


\section{Appendix B: sources and definitions}

\begin{tabular}{ll}
\hline Variable & Description \\
\hline Shadow economy & Size of the shadow economy in per- \\
cent of GDP calculated with MIMIC and \\
currency demand estimation techniques. \\
Causes: Share of direct taxation (in percent \\
of GDP), Share of indirect taxation and cus- \\
tom duties (in percent of GDP), Burden of \\
State Regulation (share of public adminis- \\
trative employment in percent of total em- \\
ployment), Unemployment quota (in percent \\
of population between 18 and 64), GDP p.c. \\
in cross domestic product divided by mid- \\
year population. Indicators: employment (as \\
percent of population 18-64), growth rate of \\
GDP per capita, change of currency (growth \\
rate of change of currency per capita).
\end{tabular}

Shadow economy, alternative measure

\section{Corruption (ICRG)}

Corruption (TI)

Corruption (World Bank)

Corruption (DKM)

GDP per capita

Fiscal burden (Heritage)
Size of the shadow economy in percent of GDP calculated with the physical input method.

Measures corruption in the political system as a threat to foreign investment based on the analysis of a worldwide network of experts. Rescaled so that 0 represents no corruption and 6 highest corruption.

Corruption Perception Index. Rescaled so that 0 represents no corruption and 10 highest corruption.

\section{Control of Corruption Index.}

Index inferred from a structural model using both the likely causes and likely effects of corruption. Causes: the rule of law, school enrollment, latitude, legal German origin, age of democracy. Indicators: Cement consumption, private credit, GDP p.c., capital account restrictions. The index ranges from 1 to 10 , where higher values represent more corruption.

GDP per capita is gross domestic product divided by midyear population. Data are in constant US dollars.

The index of the fiscal burden refers to average and marginal corporate and income taxation where a score of 1 signifies an economic environment most conducive to economic freedom, while a score of 5 signifies least economic freedom.
Source

Schneider (2005a)

Schneider and Enste (2000)

International Country Risk Guide (ICRG)

Transparency International

Kaufmann et al. (2003)

Dreher et al. (2007)

World Bank (2003)

Heritage Foundation (2005) 


\begin{tabular}{ll}
\hline Variable & Description \\
\hline
\end{tabular}

Democracy

Taxes on international trade (Fraser)

Trade barriers (Heritage)

Taxes (percent of GDP)

Revenue (percent of GDP)

Minimum wage regulation (Fraser)

Credit market regulation (Fraser)

Regulation of prices (Fraser)

Administrative procedures (Fraser)

Time with government bureaucracy (Fraser)

Wage and price regulation (Heritage)

Regulation (Heritage)

Rule of law (World Bank)

Government effectiveness (World Bank)

Judicial independence (Fraser)

Impartial courts (Fraser)

Integrity of legal system (Fraser)
0-10 $(0=$ low; $10=$ high $)$ democracy score. Measures the general openness of political institutions.

Show higher scores for countries with lower tax rates, on a scale of $1-10$.

Captures international trade taxation and regulation. A higher score implies a higher burden of taxation, i.e. higher average and marginal tax rates and, respectively, higher taxes on trade.

Tax revenue in percent of GDP.

Current revenue (excluding grants) in percent of GDP.

Show higher scores for countries with less regulation, on a scale of $1-10$.

Show higher scores for countries with less regulation, on a scale of $1-10$.

Show higher scores for countries with less regulation, on a scale of $1-10$.

Show higher scores for countries with fewer procedures, on a scale of 1-10.

Show higher scores for countries with less bureaucracy, on a scale of 1-10.

Index of wage and price regulation where a score of 1 signifies an economic environment most conducive to economic freedom, while a score of 5 signifies least economic freedom.

Index of regulation where a score of 1 signifies an economic environment most conducive to economic freedom, while a score of 5 signifies least economic freedom.

Ranges from -2.58 to 2.48 , with higher scores showing "better" environments.

Ranges -2.31 to 2.22 , with higher scores showing "better" environments.

Show higher scores for countries with greater judicial independence, on a scale of $1-10$.

Show higher scores for countries with greater impartiality, on a scale of 1-10.

Show higher scores for countries with higher integrity, on a scale of 1-10.
Marshall and Jaggers (2008)

Gwartney and Lawson (2004)

Heritage Foundation (2005)

World Bank (2003)

World Bank (2003)

Gwartney and Lawson (2004)

Gwartney and Lawson (2004)

Gwartney and Lawson (2004)

Gwartney and Lawson (2004)

Gwartney and Lawson (2004)

Heritage Foundation (2005)

Heritage Foundation (2005)

Kaufmann et al. (2003)

Kaufmann et al. (2003)

Gwartney and Lawson (2004)

Gwartney and Lawson (2004)

Gwartney and Lawson (2004) 


\begin{tabular}{ll}
\hline Variable & Description
\end{tabular}

Ethnolinguistic fractional- Fractionalization $_{j}=1-\sum_{i=1}^{n} s_{i j}^{2}$ with $s_{i j}$ ization

Latitude

Legal origin

Costs to start business

Duration to start business

Hiring flexibility index

Firing flexibility index

Religious fractionalization being the share of group $i$ in country $j$.

Absolute value of latitude.

Dummies representing French, German, Socialist, and Scandinavian legal origin.

Measures the costs of the start-up of commercial or industrial firms with up to 50 employees and start-up capital of 10 times the economy's per-capita Gross National Income. All procedures required to register a firm are counted, including screening procedures by overseeing government entities, tax- and labour-related registration procedures, health and safety procedures, and environment-related procedures. The costs of these procedures are calculated as percentage of income per capita.

Measures the duration of the start-up of commercial or industrial firms with up to 50 employees and start-up capital of 10 times the economy's per-capita Gross National Income. All procedures required to register a firm are counted, including screening procedures by overseeing government entities, tax- and labour-related registration procedures, health and safety procedures, and environment-related procedures. Time is recorded in calendar days.

The hiring cost indicator measures all social security payments (including retirement fund; sickness, maternity and health insurance; workplace injury; family allowance; and other obligatory contributions) and payroll taxes associated with hiring an employee. The cost is expressed as a percentage of the worker's salary.

The firing cost indicator measures the cost of advance notice requirements, severance payments and penalties due when dismissing a redundant worker, expressed in weekly wages.

Fractionalization $_{j}=1-\sum_{i=1}^{n} s_{i j}^{2}$ with $s_{i j}$ being the share of group $i$ in country $j$.
Alesina et al. (2003)

Easterly and Sewadeh (2001)

La Porta et al. (1999)

Djankov et al. (2002)

Djankov et al. (2002)

Botero et al. (2004)

Botero et al. (2004)

Alesina et al. (2003) 
Appendix C: Descriptive statistics (estimation sample, Table 2, column 1, full model)

\begin{tabular}{|c|c|c|c|c|}
\hline Variable & Mean & Minimum & Maximum & Standard deviation \\
\hline Shadow economy & 33.11 & 8.55 & 68.20 & 14.18 \\
\hline Shadow economy, alternative measure & 32.15 & 9.30 & 76.00 & 15.13 \\
\hline Corruption (ICRG) & -2.94 & -6.00 & -0.33 & 1.20 \\
\hline Corruption (DKM) & 4.72 & 1.00 & 10.00 & 1.97 \\
\hline Corruption (World Bank) & -0.22 & -2.47 & 1.41 & 1.09 \\
\hline Corruption (TI) & -4.81 & -9.95 & -0.40 & 2.34 \\
\hline Log GDP per capita & 7.96 & 4.48 & 10.60 & 1.57 \\
\hline Trade barriers (Heritage) & 3.11 & 1.00 & 5.00 & 1.16 \\
\hline Administrative procedures (Fraser) & 4.07 & 1.30 & 7.03 & 1.04 \\
\hline Wage and price regulation (Heritage) & 2.52 & 1.00 & 4.00 & 0.65 \\
\hline Fiscal burden (Heritage) & 3.67 & 1.47 & 5.00 & 0.65 \\
\hline Regulation (Heritage) & 3.24 & 1.00 & 5.00 & 0.78 \\
\hline Democracy & 6.44 & 0.00 & 10.00 & 3.51 \\
\hline Taxes on international trade (Fraser) & 7.46 & 3.30 & 10.00 & 1.60 \\
\hline Taxes (percent of GDP) & 20.40 & 7.18 & 37.66 & 8.16 \\
\hline Revenue (percent of GDP) & 23.54 & 0.04 & 43.07 & 8.91 \\
\hline Credit market regulations (Fraser) & 7.11 & 2.97 & 9.73 & 1.46 \\
\hline Minimum wage regulation (Fraser) & 3.94 & 1.90 & 5.10 & 0.74 \\
\hline Regulation of prices (Fraser) & 5.24 & 1.33 & 10.00 & 1.86 \\
\hline Time with government bureaucracy (Fraser) & 5.78 & 2.80 & 7.97 & 1.19 \\
\hline Rule of law (World Bank) & 0.27 & -1.79 & 2.13 & 1.01 \\
\hline Government effectiveness (World Bank) & 0.28 & -1.62 & 2.37 & 0.99 \\
\hline Judicial independence (Fraser) & 5.13 & 0.35 & 9.30 & 2.37 \\
\hline Impartial courts (Fraser) & 5.28 & 1.70 & 8.93 & 1.91 \\
\hline Integrity of legal system (Fraser) & 6.40 & 1.70 & 10.00 & 2.41 \\
\hline Duration to start business & 51.36 & 2.00 & 203.00 & 38.34 \\
\hline Costs to start business & 60.68 & 0.00 & 711.90 & 109.10 \\
\hline Hiring flexibility index & 47.62 & 17.00 & 81.00 & 17.70 \\
\hline Firing flexibility index & 37.11 & 1.00 & 73.00 & 18.09 \\
\hline Ethnolinguistic fractionalization & 0.41 & 0.00 & 0.93 & 0.25 \\
\hline Religious fractionalization & 0.43 & 0.00 & 0.86 & 0.23 \\
\hline Latitude & 28.19 & 0.23 & 60.21 & 17.36 \\
\hline Legal origin British & 0.31 & 0.00 & 1.00 & 0.46 \\
\hline Legal origin French & 0.48 & 0.00 & 1.00 & 0.50 \\
\hline Legal origin Socialist & 0.12 & 0.00 & 1.00 & 0.32 \\
\hline Legal origin German & 0.05 & 0.00 & 1.00 & 0.22 \\
\hline Legal origin Scandinavian & 0.04 & 0.00 & 1.00 & 0.20 \\
\hline
\end{tabular}




\section{Appendix D: Countries included in the analysis}

\begin{tabular}{lll}
\hline Albania & Haiti & Papua New Guinea \\
Algeria & Honduras & Paraguay \\
Argentina & Hungary & Peru \\
Australia & India & Philippines \\
Austria & Indonesia & Poland \\
Bangladesh & Iran, Islamic Rep. & Portugal \\
Belgium & Ireland & Romania \\
Bolivia & Israel & Russian Federation \\
Botswana & Italy & Senegal \\
Brazil & Jamaica & Singapore \\
Bulgaria & Japan & Slovak Republic \\
Cameroon & Jordan & Slovenia \\
Canada & Kenya & South Africa \\
Chile & Korea, Rep. & Spain \\
China & Kuwait & Sri Lanka \\
Colombia & Latvia & Sweden \\
Congo, Dem. Rep. & Lithuania & Switzerland \\
Costa Rica & Madagascar & Syrian Arab Republic \\
Cyprus & Malawi & Tanzania \\
Czech Republic & Malaysia & Thailand \\
Denmark & Mali & Togo \\
Dominican Republic & Mexico & Tunisia \\
Ecuador & Morocco & Turkey \\
Egypt, Arab Rep. & Namibia & Uganda \\
El Salvador & Netherlands & Ukraine \\
Estonia & New Zealand & United Arab Emirates \\
Finland & Nicaragua & United Kingdom \\
France & Niger & United States \\
Gabon & Nigeria & Uruguay \\
Germany & Norway & Venezuela, RB \\
Ghana & Oman & Zambia \\
Greece & Pakistan & Zimbabwe \\
Guatemala & Panama & \\
\hline & & \\
\hline
\end{tabular}

\section{References}

Aidt, T., \& Gassebner, M. (2007). Do autocratic states trade less? Cambridge Working Papers in Economics 0742 .

Alesina, A., Easterly, W., Devleeschauwer, A., Kurlat, S., \& Wacziarg, R. (2003). Fractionalization. Journal of Economic Growth, 8, 155-194.

Bardhan, P. (1997). Corruption and development: a review of issues. Journal of Economic Literature, 3, $1320-1346$.

Bjørnskov, C. (2006). The multiple facets of social capital. European Journal of Political Economy, 22(1), $22-40$. 
Botero, J., Djankov, S., La Porta, R., Lopez de Silanes, F., \& Shleifer, A. (2004). The regulation of labour. Quarterly Journal of Economics, 119, 1339-1382.

Choi, J., \& Thum, M. (2005). Corruption and the shadow economy. International Economic Review, 46(3), $817-836$.

Djankov, S., La Porta, R., Lopez de Silanes, F., \& Schleifer, A. (2002). The regulation of entry. Quarterly Journal of Economics, 117, 1-37.

Dreher, A., Kotsogiannis, C., \& McCorriston, S. (2007). Corruption around the world: evidence from a structural model. Journal of Comparative Economics, 35(3), 443-466.

Dreher, A., Kotsogiannis, C., \& McCorriston, S. (2008, forthcoming). How do institutions affect corruption and the shadow economy? International Tax and Public Finance.

Dreher, A., \& Siemers, L.-H. R. (2009). The nexus between corruption and capital account restrictions. Public Choice, 140(1-2), 245-265.

D'Hernoncourt, J., \& Méon, P.-G. (2008). The not so dark side of trust: does trust increase the size of the shadow economy? CEB Working Paper No. 08/030.

Easterly, W., \& Sewadeh, M. (2001). Global development network growth database. http://www.worldbank. org/research/growth/GDNdata.htm.

El-Shagi, M. (2005). A legal crime: capital controls as an act of corruption. Mimeo, University of Mannheim.

Friedman, E., Johnson, S., Kaufmann, D., \& Zoido-Lobatón, P. (2000). Dodging the grabbing hand: the determinants of unofficial activity in 69 countries. Journal of Public Economics, 76, 459-493.

Gerxhani, K. (2003). The informal sector in developed and less developed countries: a literature survey. Public Choice, 114(3), 295-318.

Gwartney, J., \& Lawson, R. (2004). Economic freedom of the world: 2004 annual report. Vancouver: The Fraser Institute. Data retrieved from www.freetheworld.com.

Helberger, C., \& Knepel, H. (1988). How big is the shadow economy? A re-analysis of the unobservedvariable approach of B.S. Frey and H. Weck-Hannemann. European Economic Review, 32, 965-976.

Heritage Foundation (2005). Index of Economic Freedom. Washington, DC.

Hibbs, D. A., Jr., \& Piculescu, V. (2005). Institutions, corruption and tax evasion in the unofficial economy. Göteborg, Department of Economics.

Hindriks, J., Muthoo, A., \& Keen, M. (1999). Corruption, extortion and evasion. Journal of Public Economics, 74, 395-430.

La Porta, R., Lopez de Silanes, F., Shleifer, A., \& Vishny, R. W. (1999). The quality of government. Journal of Law, Economics, and Organization, 15(1), 222-279.

Johnson, S., Kaufmann, D., \& Shleifer, A. (1997). The unofficial economy in transition. Brookings Papers on Economic Activity, 2, 159-221.

Johnson, S., Kaufmann, D., \& Zoido-Lobatón, P. (1998). Corruption, public finances and the unofficial economy. World Bank Policy Research Working Paper Series 2169.

Kaufmann, D., Kraay, A., \& Mastruzzi, M. (2003). Governance matters III: Governance indicators for 19962002. World Bank Policy Research Working Paper 3106.

Klitgaard, R. (1988). Controlling corruption. Berkeley: University of California Press.

Loayza, N. V. (1996). The economics of the informal sector: a simple model and some empirical evidence from Latin America. Carnegie-Rochester Conference Series on Public Policy, 45, 129-162.

Marshall, M. G., \& Jaggers, K. (2008). Polity IV project: political regime characteristics and transitions, 1800-2008. http://www.systemicpeace.org/polity/polity4.htm.

Méon, P.-G., \& Sekkat, K. (2004). Does the quality of institutions limit the MENA's integration in the world economy? The World Economy, 27(9), 1475-1498.

Méon, P.-G., \& Sekkat, K. (2005). Does corruption grease or sand the wheels of growth? Public Choice, 122(1-2), 69-97.

Méon, P.-G., \& Weill, L. (2006, forthcoming). Is corruption an efficient grease? World Development.

Mocan, N. (2004). What determines corruption? International evidence from micro data. NBER Working Paper 10460.

Otáhal, T. (2007). Why is corruption a problem of the state? Prague Economic Papers, 2, 165-179.

Pitlik, H., Frank, B., \& Firchow, M. (2009, forthcoming). The demand for transparency: an empirical note. Review of International Organizations.

Rose-Ackerman, S. (1999). Corruption and government: Causes, consequences and reform. Cambridge: Cambridge University Press.

Schneider, F. (2005a). Shadow economies of 145 countries all over the world: estimation results of the period 1999-2003. University of Linz: Department of Economics, Discussion paper Linz, Austria.

Schneider, F. (2005b). Shadow economies around the world: what do we really know? European Journal of Political Economy, 21(3), 598-642. 
Schneider, F., \& Enste, D. H. (2000). Shadow economies: size, causes, and consequences. Journal of Economic Literature, 38, 77-114.

Shleifer, A., \& Vishny, R. W. (1993). Corruption. Quarterly Journal of Economics, CVIII, 599-618.

Søreide, T. (2005). Is it right to rank? Limitations, implications and potential improvements of corruption indices. Paper presented to IV Global Forum on Fighting Corruption and Safeguarding Integrity, Session Measuring Integrity, June 7, 2005.

Weber Abramo, C. (2005). How far perceptions go. Transparency Brazil Working Paper.

World Bank (2003). World development indicators. CD-Rom, Washington, DC. 